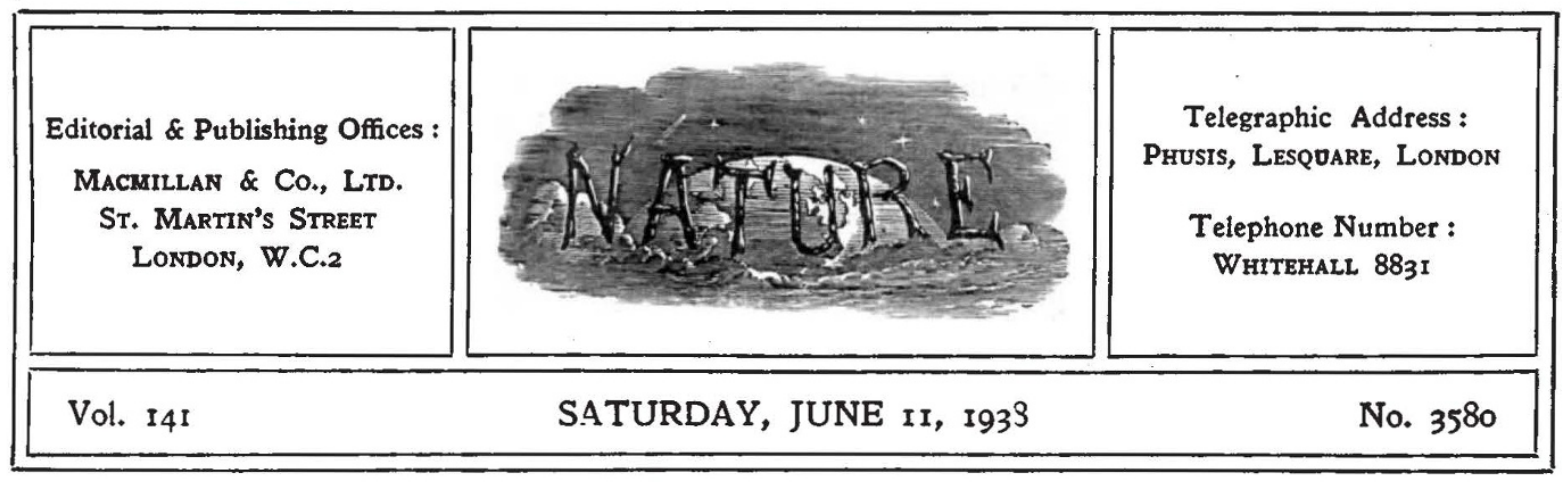

\title{
Archæological Studies in Ireland
}

I RELAND, for long not so much a neglected corner in the archæological field as the victim of a provincial outlook, is to come into her own as an element in the mosaic of European prehistory. She is at last to take her proper place in the pattern which a band of workers closely in touch with one another is rapidly piecing together, more especially in the north-western sector of Europe, of the early movements of cultures and peoples, from which has emerged the complex of modern Western civilization. To say this is not to ignore the achievement of Ireland's archæologists and historians in the past, many of them, like Sir William Wilde and George Coffey, of international repute. Granting these exceptions, in little more than a decade there has been a change in the spirit and orientation of Irish archæology which has diverted interest from exclusive preoccupation with Ireland as a unitary region, or as an appendage of Britain only, in such studies, and their bearing on the identification and history of the mythical races and peoples of early Ireland, to the wider horizon of the correlation of her development in civilization with that of Great Britain and the Continental mainland. The story of this change has been told recently by Dr. Adolf Mahr, keeper of antiquities and director of the National Museum of Ireland, in his presidential address for 1937 to the Prehistoric Society, of which a digest appears on another page of this issue of NaTuRE (see p. 1041).

To those familiar with the material, it may appear that even less than justice has been done to a remarkable achievement. In no more than one hundred and seventy-five pages-though assuredly the longest presidential address ever presented to a learned society-Dr. Mahr has summarized, discussed and placed in its true archæological perspective the great store of new information accruing in the last five years from the intensive archæological investigations which have been carried on in the Irish field. This information has been analysed and brought into relation not only with the cultural succession of Ireland's own prehistory, but also with the general archæological complex in northern Europe of the prehistoric period as a whole. In range it surveys from the alleged, but now disputed, Upper Palæolithic man of the Kilgreany cave in Co. Waterford, down to the Early Iron Age, and even beyond in an occasional glance over Dr. Mahr's selfimposed barrier into the Early Christian period, commonly known as Late Celtic. In passing from one period to another the survey pauses to discuss problems intrinsically fascinating, but even more compelling as vital for the understanding of Ireland's part in the general development of prehistoric culture as a whole.

Among these topics of discussion, the lithic civilization of the 'Riverford' people, newly recognized by Dr. Mahr himself in a culture which in Ireland appears to centre on the Bann River, is one of the first importance. Ultimately derivative from the Baltic Maglemose, and a manifestation of Prof. Gordon Childe's 'forest culture', it takes us back to the very springs of civilization in northern Europe, and it may be, as Dr. Mahr suggests, the clue to the identification of that ethnically obscure stratum in the peoples of Britain, the Picts-a suggestion which in its ramifications opens up interesting vistas of further research.

Scarcely less significant is the story of the Irish megalith, now told in the light of the recent crucial excavations of the 'horned' cairns of 
northern Ireland, and in relation to its bearing on the origin of the 'Iberic' element in the Irish population, the development of the Irish Bronze Age, and the survival of non-Aryan traits in Irish culture.

With the Late Bronze Age early in the last millennium before Christ there comes the break in culture and the incursion of a new people from Central Europe, the Celts. If they herald what is to most the very dawn of Ireland's greatness as the centre of culture she became in later centuries, they have also left a legacy of problems to puzzle modern generations--their origin, their distribution, and the relation of the two branches of the Celtic-speaking peoples, the $q$ Celts and the $p$ Celts, both to one another and in the composition of the British and Irish peoples-matters of perennial argument to which the latest research in Ireland contributes its quota. These problems are further complicated by the novel line of evidence of pollen analysis of the peat, which while it has afforded a new and assured datum line in late glacial and early post-glacial times in Ireland, threatens, as at present understood, to throw into confusion the chronology of the Late Bronze Age.

It is a temptation to follow further the fascinating array of problems, which have already engaged the attention of the archæologist, or lie before him in the prospect of further research, more especially in the field of recreating the religious and social concepts of the ancient civilization of Ireland, so far as this is possible by the interpretation of the evidence of archæology and of surviving custom and belief. On such matters, however, reference must be made to the text of Dr. Mahr's address. Enough has been said to indicate that archæological studies in Ireland are well advanced along a path which will lead not only to fuller knowledge and understanding of Irish civilization from the earliest phases through the cycle of its full development to eclipse, but by bringing it into touch with the European background will enable it to add its contribution to studies in a wider field.

For this great expansion in Irish archæological studies in the last decade no single circumstance, or set of circumstances, is entirely responsible. That the zeal of Harvard University for scientific research for its own sake inspired a like enthusiasm and emulation in Ireland is unquestionable; but credit is mainly due to the public spirit and the vision of the Governments of Eiré and of Northern Ireland in directing measures for the relief of unemployment out of public funds into the channel of archæological excavation. But zeal without understanding is blind, and it was fortunate for Irish studies that there were among the men of science of Ireland those who were able to take advantage of their opportunities and devise a campaign of systematic research, from which the greatest and most generally valuable increase in the sum of knowledge might accrue. Even so, the gain might have been less, had it not been possible for Northern Ireland and Eiré to work in complete harmony and with the fullest measure of co-operation. Archæology in Ireland knows no political or geographical boundaries.

\section{Newton}

Isaac Newton, I642-I727

By J. W. N. Sullivan. With a Memoir of the Author by Charles Singer. Pp. $x x+275$. (London : Macmillan and Co., Ltd., 1938.) 8s. 6d. net.

$\mathrm{A}^{\mathrm{s}}$ the arts aspire to the nature of music, according to Pater, so the sciences aspire to the nature of mathematics. This at least would seem to have been the view of the late Mr. J. W. N. Sullivan when he devoted two of the principal efforts of his life, one to a work on Beethoven, the other to a work on Newton. From Prof. Charles Singer's memoir of the author, it appears that the latter was ten years in preparation. Even then the absence of chapter headings and occasional repetitions suggest that some final revision may have been intended. But a perfectly satisfactory manuscript existed at the time of the author's early death, and the book is in all essential respects a finished work.

This study deserves a respectful welcome, because it is a serious contribution in a field of literature which has been for the most part conspicuously neglected. While the lives of great artists, and of musicians in particular, have been studied over and over again with the most minute care, the lives of the great masters of science have generally been allowed to pass quickly into oblivion. The literature which has gathered round Wagner, for example, must already be immense. Even second-rate masters receive their tribute on a slightly lower scale. But in general the work of 